\title{
Evaluating Inclusive Campus Environment Design Criteria Using CFPR and FANP Methodologies
}

\author{
KEMAL GÖKHAN NALBANT \\ Department of Software Engineering \\ Beykent University \\ Hadim Koruyolu Street, 34936, Sariyer, Istanbul \\ TURKEY \\ ORCID-ID: 0000-0002-5065-2504 \\ ŞAHIKA ÖZDEMIR \\ Department of Interior Architecture and Environmental Design \\ Istanbul Sabahattin Zaim University \\ Halkali Street, 34303, Halkali Kucukcekmece, Istanbul \\ TURKEY \\ ORCID-ID: 0000-0002-5762-1962 \\ YAVUZ ÖZDEMİR \\ Institute of Science and Technology \\ Istanbul Sabahattin Zaim University \\ Halkali Street, 34303, Halkali Kucukcekmece, Istanbul \\ TURKEY \\ ORCID-ID: 0000-0001-6821-9867
}

\begin{abstract}
University campuses bring together individuals from different socio-cultural backgrounds. At the same time, university campuses contribute to the personal and intellectual development of individuals and serve as a socialization area. Campuses create vitality with their social, cultural, economic, and spatial effects. In this paper, we study for evaluating inclusive campus environment design criteria using the Fuzzy Analytical Network Process (FANP) and Consistent Fuzzy Preference Relations (CFPR) techniques, which are two MultiCriteria Decision Making (MCDM) methods. Seven Inclusive Campus Environment Design Criteria are "Land Use Organization", "Compactness", "Connectivity", "Configuration", "Living campus", "Greens" and "Context". The major contribution of our study is to prioritize inclusive campus environment design criteria by using numerical methods from the decision maker's perspective. According to the authors' knowledge, this will be the first interdisciplinary study to use MCDM methods for evaluating inclusive campus environment design criteria. Additionally, the results of both methodologies are compared.
\end{abstract}

Key-Words: - Campus climate; Inclusive design; Decision making; Fuzzy Logic; CFPR; Fuzzy ANP.

Received: April 23, 2021. Revised: July 26, 2021. Accepted: July 28, 2021. Published: August 2, 2021.

\section{Introduction}

Every individual who lives in the city and can participate in daily life in public spaces has the right to benefit equally from the opportunities and opportunities provided by the town where he lives. The concept of Inclusive Design has emerged to enable people to reach the current options as equally as possible [1], and it is defined as the process of designing products and environments that many people can use in many possible situations [2].
Since the city's public spaces have an important place in urban development, they should be shaped according to need. Campuses emerge as critical public spaces, as they function as small cities thanks to their facilities and social environment. Campus areas affect our attitudes towards education and should be shaped according to need and designed to include all campus users [3].

Universities are institutions that play a locomotive role in the development and direction of the cities and regions they are located in. Therefore 
all users have equal rights and laws and set an example for the accessibility of everyone in spatial and physical terms. The accessibility and accessibility of all people who have to use the campus from students, employees, or campuses must be provided by these institutions. Universities are also among the institutions that need to be most sensitive about the accessibility of all places in terms of education, work, and right to life for individuals with disabilities, which cannot be ignored anymore [4].

The campus environment results in a diversity of individuals from different backgrounds. To lay the foundation for a learning community, the academy's primary mission should be to create an environment fostering diversity and understanding the difference.

According to [5], a comprehensive campus plan requires the following criteria;

- Prioritizing the general plan over individual buildings,

- Compactness to create vitality and interaction possibilities for using the campus,

- Environmental aspects are adopted,

- Being repairable,

- Visually sufficient by using the campus architecture,

- Availability of integration technology,

- Establishing a beneficial physical relationship with the campus environment.

Selecting or prioritizing alternatives from a range of available alternatives based on multi-criteria is referred to as MCDM. There are many methodologies within MCDM. Each method has different characteristics [6].

MCDM is a methodological and modeling tool used to deal with complex engineering problems. Experts face many issues with unclear and incomplete information in MCDM issues. Because the characteristics of these problems frequently require such knowledge [7].

We can list the steps of MCDM as follows [8]:

1. Establish evaluation criteria that link capabilities to goals.

2. Build an alternative system to succeed objectives.

3. Evaluate alternatives according to criteria.

4. Apply a standard multi-criteria evaluation methodology.

5. Choose one alternative as "optimal".

6. If it's not considered the final solution, collect information, and move to the next iteration of multicriteria optimization.
In this paper, we applied CFPR and FANP methodologies to select the best inclusive campus environment design criteria. There are so many papers that use the CFPR methodology for MCDM problems in the literature. Patel et al. [9] used the CFPR method to compute the hazard index representing the hazard level of projects. Alias and Abdullah [10] assessed criteria that determine the quality of life (QoL) among the population in Setiu Wetlands by using the CFPR method. Chao [11] used the AHP model to construct the hierarchy of criteria and used the CFPR to evaluate the multicriteria for the selection of a smartphone. Cheng et al. [12] developed the CFPR-ANP methodology to obtain preference-weights of criteria for Research and Development (R\&D) Project Selection. Ozdemir et al. [13] determined personnel selection criteria and prioritized these criteria by CFPR. Alias et al. [14] proposed a modified approach of consistent fuzzy preference relation with geometric Bonferroni mean operator for assessing the quality of life. Park et al. [15] utilized the CFPR method, which handles both quantitative and qualitative factors to choose optimal routes for small and medium ports (SMPs). Huynh and Phi [16] applied CFPR to select a strategy that attracts Foreign Direct Investment in developing industries for Vietnam.

Many studies use the FANP method for MCDM problems in the literature. Hemmati et al. [17] constructed the FANP model and applied it to a sulfuric acid production facility for selecting the maintenance policy. Danai et al. [18] proposed an FANP method for selecting the best supplier in the supply chain. Alilou et al. [19] developed a novel framework to assess watershed health using the FANP method considering topo-hydrological and geo-environmental criteria. Galankashi et al. [20] developed specific criteria and an FANP method to prioritize and select portfolios on the Tehran Stock Exchange (TSE). Many studies use MCDM methods in the literature [21-28].

The rest of this study is organized as follows: a short explanation for an inclusive campus climate is given in the 2nd section. CFPR and FANP methodologies are examined in the 3rd and 4th sections, respectively. An application of CFPR and FANP methodologies in evaluating inclusive campus environment design criteria and computational results are given in the 5th section. Finally, future research directions and a comparison of the results are discussed in the 6th section. 


\section{Inclusive Campus Environment Design}

Architecture is experienced from the moment it approaches the site and building from the street. The form can be seen by the eye, which gives information about the physical environment. Therefore, inclusive buildings must be architecturally fully accessible for use by people regardless of age and abilities. In campus design, the administration's inclusion target and perception should be this approach. It should use inclusive architecture as communication when people walk around and experience the building [3].

The criteria to be considered in designing an inclusive campus environment are explained in the following headings [29].

Land Use Organization: It is necessary to offer sports, research, housing and different academic opportunities in conjunction with each other. Kenney et al. [5] that combining possibilities has social, educational and financial benefits; increased vocational education and society; learning; security; competitive acceptance; $\mathrm{He}$ said it provides flexibility for growth.

Compactness: It is necessary to ensure the campus density and the proximity of the buildings. Kenney et al. [5] stated that "physical intensity, walking from place to place more easily in students and staff, encourages interaction and strengthens the sense of corporate identity".

Connectivity: Street network connection degree within the campus, the campus and its surroundings should be connected.

Configuration: Scale and design to emphasize new buildings, creating a focal point at the pedestrian axis end, achieving prominent visual corridors, emphasizing outdoor foci it is necessary to make changes, to switch between different areas on the campus, to maintain and increase the appearance of character-defining features.

Living campus: It is necessary to increase the campus life degree, that is, the time spent on the campus. It is necessary to improve housing on campus, expand and diversify housing options on campus. The increase in campus housing can impact on campus sustainability by reducing learning, livability, sense of community, and student commute.

Greenness: The naturalness or the greenness level should be sufficient. To create vivid open spaces, it is necessary to design landscapes, protect park-like campuses, provide a view between buildings, provide a view of city streets, fulfill ecological functions to develop local vegetation by integrating it into the campus landscape. Coulson et al. [30], "Nature, recognized for both its beauty and uplift, became one of the most notable aspects in the location... the natural environment was organized to benefit the well-being and moral character of students for the well-being of the people".

Context: The degree of surrounding urbanism affects the campus environment. To create a mixeduse campus town with the city, it is necessary to develop a street corridor, to construct conference centers, student cafeterias, student clubs [31].

\section{Consistent Fuzzy Preference Relations Method (CFPR)}

Herrera-Viedma et al. [32] introduced CFPR by reducting the pairwise comparison. The methodology only requires $n-1$ judgments for a preference matrix with $n$ elements. Furthermore, CFPR reduces decision-making times, so it provides better consistency. It determines the relative importance of main criteria and subcriteria using the calculation procedure $[33,34]$.

Steps of the CFPR method are used in this study $[35,36]$. Linguistic terms and corresponding numbers are used to obtain pairwise comparisons and can be seen in Table 1 .

Table 1. Linguistic scale.

\begin{tabular}{|l|c|}
\hline \multicolumn{1}{|c|}{ Definition } & Relative Importance \\
\hline Intermediate values & $2,4,6,8$ \\
\hline Equally important & 1 \\
\hline Moderately more important & 3 \\
\hline Strongly more important & 5 \\
\hline Very strongly more important & 7 \\
\hline Absolutely more important & 9 \\
\hline
\end{tabular}

\section{Fuzzy Analytic Network Process Method (FANP)}

Saaty [37] introduced the Analytical Network Process (ANP) and suggested using ANP to find the solution to the problem between alternatives or criteria [38]. ANP method is used to evaluate the priorities of the alternatives of the goal and the elements in the network. Buckley's Fuzzy AHP algorithm [39, 40, 41] based FANP is used for weighting the inclusive campus environment design criteria in this paper.

The steps of FANP are used in this study [42, 43]. To solve the problem with the FANP method, fuzzy numbers are used as shown in Table 2. 
Table 2. Degrees of linguistic importance and relation between fuzzy numbers.

\begin{tabular}{|c|c|c|}
\hline \multicolumn{2}{|c|}{ High/Low Levels } & \multirow{2}{*}{ Fuzzy Numbers } \\
\hline Label & Linguistic Terms & \\
\hline Extra High & EH & $(9,9,9)$ \\
\hline Very High & VH & $(7,9,9)$ \\
\hline High & H & $(5,7,9)$ \\
\hline Slightly High & SH & $(3,5,7)$ \\
\hline Middle & M & $(1,3,5)$ \\
\hline Slightly Low & SL & $(1,1,3)$ \\
\hline Just equal & E & $(1,1,1)$ \\
\hline
\end{tabular}

\section{APPLICATION}

In this paper, we apply CFPR and FANP methodologies to prioritize the inclusive campus environment criteria. 7 main criteria and 31 subcriteria were determined and weighted accordingly [3]. 3 experts with the same importance value from academia were asked about weighting the criteria. The main criteria and the subcriteria are as seen in Fig. 1.

"Land Use Organization" (MC1) criteria includes subcriteria as "Integrating Academic and Research Activities in Common Facilities" (SC11), "Bringing Together Communities of Different Disciplines" (SC12), "Concentrating the Campus and Workplace, Including Housing and Activities" (SC13), and "Converting Low-Intensity Land Uses into Athletic Areas and Greenhouses" (SC14).

"Compactness" (MC2) criteria contains subcriteria as "Having as many University Functions as Possible in the Center or Close to it" (SC21), "Limiting the Use of Fillers and Restricting Movement where Possible" (SC22), and "Making Programs to Encourage Interdisciplinary Cooperation" (SC23).

"Connectivity" (MC3) criteria consist of from "Development of New Pedestrian Paths, Walking Areas and Passages" (SC31), "Green Corridors to Connect Different Parts of the Campus" (SC32), "Development of Strong Physical Connections between the Campus and the Neighborhood" (SC33), "Additional Campus Entrances" (SC34).

"Configuration" (MC4) criteria includes "Scaling and Designing to Emphasize New Buildings" (SC41), "Creating Semi-Enclosed Spaces with Many Entrances" (SC42), "Creating a Focal Point at the Pedestrian Axis End" (SC43), "Placing Towers or Other Prominent Building Elements at Focal Points" (SC44), "Emphasizing Outdoor Foci It Is Necessary to Make Changes, to Switch between Different Areas on the Campus" (SC45), "Carrying
Out a Series of Open Space Projects to Help Illuminate the Pedestrian Paths" (SC46), "Providing Hierarchy" (SC47), "Maintaining and Increasing the Appearance of Character-Defining Features" (SC48) subcriteria.

"Living campus" (MC5) criteria contain subcriteria as "Increasing Housing on Campus" (SC51), "Expanding and Diversifying Housing Options on Campus" (SC52), "Establishing Multidisciplinary Academic Facilities and Position them in the Core Campus" (SC53).

"Greenness" (MC6) criteria includes the following subcriteria: "Designing Landscapes to Create Vivid Open Spaces" (SC61), "Protect ParkLike Campuses" (SC62), "Providing a View between Buildings, Provide a View of City Streets" (SC63), "Fulfilling Ecological Functions to Create a more Manageable Parking Space" (SC64), and "Developing Local Vegetation by Integrating it into the Campus Landscape" (SC65).

"Context" (MC7) criteria contains these subcriteria: "Creating a Mixed-Use Campus Town with the City, to Create a Street Corridor" (SC71), "Constructing Conference Centers, Student Cafeterias, Student Clubs, Theaters and Alumni Centers" (SC72), "Encouraging Private Development and Investment" (SC73), and "Considering the Campus as a Destination for the Public" (SC74).

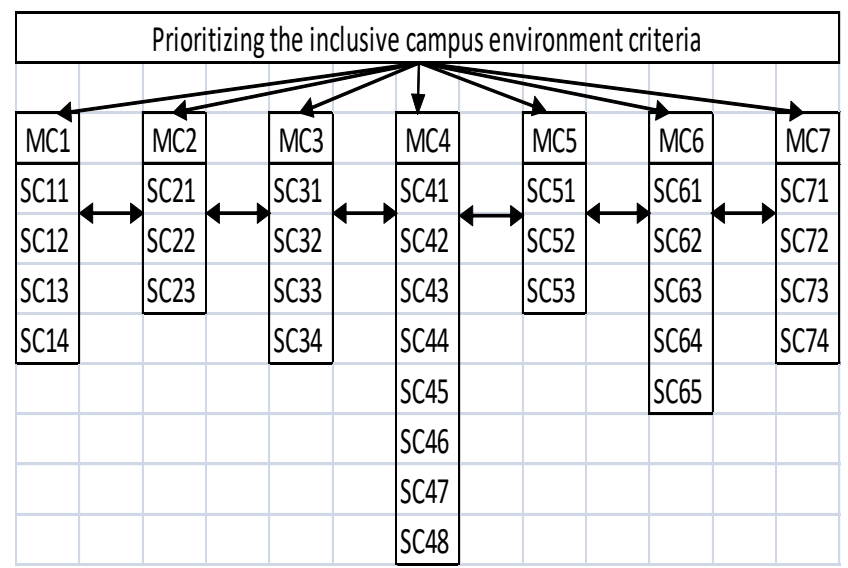

Figure 1. Network of the problem.

\subsection{Computational Results of the CFPR methodology}

For the computations of CFPR methodology, all experts were asked to determine the importance of different main criteria and sub-criteria based on Table 1. The pairwise comparison matrices for the main criteria and sub-criteria (SC11) were provided by decision maker 1 are shown in Table 3 and Table 4 , respectively. 
Table 3. Fuzzy preference pairwise comparison matrix of decision maker 1 for the main criteria.

\begin{tabular}{|l|c|c|c|c|c|c|c|}
\hline & MC1 & MC2 & MC3 & MC4 & MC5 & MC6 & MC7 \\
\hline MC1 & 1 & 0.333 & & & & & \\
\hline MC2 & & 1 & 0.2 & & & & \\
\hline MC3 & & & 1 & 7 & & & \\
\hline MC4 & & & & 1 & 0.333 & & \\
\hline MC5 & & & & & 1 & 0.2 & \\
\hline MC6 & & & & & & 1 & 5 \\
\hline MC7 & & & & & & & 1 \\
\hline
\end{tabular}

Table 4. Fuzzy preference pairwise comparison matrix of decision maker 1 for the sub-criteria (MC1).

\begin{tabular}{|c|c|c|c|c|}
\hline & SC11 & SC12 & SC13 & SC14 \\
\hline SC11 & 1 & 0.143 & & \\
\hline SC12 & & 1 & 5 & \\
\hline SC13 & & & 1 & 5 \\
\hline SC14 & & & & 1 \\
\hline
\end{tabular}

Then, the remaining $p_{i j}^{k}$ for main and sub-criteria are calculated by using CFPR method (Table 5, 6).

Table 5. Transformed fuzzy preference values of decision maker 1 for the main criteria.

\begin{tabular}{|c|c|c|c|c|c|c|c|}
\hline & MC1 & MC2 & MC3 & MC4 & MC5 & MC6 & MC7 \\
\hline MC1 & 0.5 & 0.25 & -0.116 & 0.327 & 0.077 & -0.290 & 0.077 \\
\hline MC2 & 0.75 & 0.5 & 0.134 & 0.577 & 0.327 & -0.040 & 0.327 \\
\hline MC3 & 1.116 & 0.866 & 0.5 & 0.943 & 0.693 & 0.327 & 0.693 \\
\hline MC4 & 0.673 & 0.423 & 0.057 & 0.5 & 0.25 & -0.116 & 0.25 \\
\hline MC5 & 0.923 & 0.673 & 0.307 & 0.75 & 0.5 & 0.134 & 0.5 \\
\hline MC6 & 1.290 & 1.040 & 0.673 & 1.116 & 0.866 & 0.5 & 0.866 \\
\hline MC7 & 0.923 & 0.673 & 0.307 & 0.75 & 0.5 & 0.134 & 0.5 \\
\hline
\end{tabular}

Table 6. Transformed fuzzy preference values of decision maker 1 for the sub-criteria.

\begin{tabular}{|c|c|c|c|c|}
\hline & SC11 & SC12 & SC13 & SC14 \\
\hline SC11 & 0.5 & 0.057 & 0.423 & 0.790 \\
\hline SC12 & 0.943 & 0.5 & 0.866 & 1.232 \\
\hline SC13 & 0.577 & 0.134 & 0.5 & 0.866 \\
\hline SC14 & 0.210 & -0.232 & 0.134 & 0.5 \\
\hline
\end{tabular}

Preference values transformed by transformation function for main and sub-criteria are obtained by the CFPR method (Table 7, 8).
Table 7. Preference values transformed by transformation function for the main criteria.

\begin{tabular}{|c|c|c|c|c|c|c|c|}
\hline & MC1 & MC2 & MC3 & MC4 & MC5 & MC6 & MC7 \\
\hline MC1 & 0.5 & 0.342 & 0.110 & 0.390 & 0.232 & 0 & 0.232 \\
\hline MC2 & 0.658 & 0.5 & 0.268 & 0.548 & 0.390 & 0.158 & 0.390 \\
\hline MC3 & 0.890 & 0.732 & 0.5 & 0.780 & 0.622 & 0.390 & 0.622 \\
\hline MC4 & 0.610 & 0.452 & 0.220 & 0.5 & 0.342 & 0.110 & 0.342 \\
\hline MC5 & 0.768 & 0.610 & 0.378 & 0.658 & 0.5 & 0.268 & 0.5 \\
\hline MC6 & 1 & 0.842 & 0.610 & 0.890 & 0.732 & 0.5 & 0.732 \\
\hline MC7 & 0.768 & 0.610 & 0.378 & 0.658 & 0.5 & 0.268 & 0.5 \\
\hline
\end{tabular}

Table 8. Preference values transformed by transformation function for the sub-criteria.

\begin{tabular}{|c|c|c|c|c|}
\hline & SC11 & SC12 & SC13 & SC14 \\
\hline SC11 & 0.5 & 0.198 & 0.448 & 0.698 \\
\hline SC12 & 0.802 & 0.5 & 0.75 & 1 \\
\hline SC13 & 0.552 & 0.25 & 0.5 & 0.75 \\
\hline SC14 & 0.302 & 0 & 0.25 & 0.5 \\
\hline
\end{tabular}

Likewise, the fuzzy preference relation matrices of the other 2 decision-makers for all main and subcriteria are calculated by using the above computational procedure.

To integrate the judgments of 3 decision-makers, the CFPR method is used and the aggregated pairwise comparison matrices for main and sub-criteria are shown in Table 9 and Table 10, respectively.

Table 9. Aggregated pairwise comparison matrix of 3 decision makers for the main criteria.

\begin{tabular}{|c|c|c|c|c|c|c|c|}
\hline & MC1 & MC2 & MC3 & MC4 & MC5 & MC6 & MC7 \\
\hline MC1 & 1.5 & 1.591 & 1.191 & 1.640 & 1.232 & 0.75 & 1.521 \\
\hline MC2 & 1.408 & 1.5 & 1.099 & 1.548 & 1.140 & 0.658 & 1.429 \\
\hline MC3 & 1.809 & 1.901 & 1.5 & 1.949 & 1.541 & 1.059 & 1.830 \\
\hline MC4 & 1.360 & 1.452 & 1.051 & 1.5 & 1.092 & 0.610 & 1.381 \\
\hline MC5 & 1.768 & 1.860 & 1.459 & 1.908 & 1.5 & 1.018 & 1.789 \\
\hline MC6 & 2.25 & 2.342 & 1.941 & 2.390 & 1.982 & 1.5 & 2.271 \\
\hline MC7 & 1.479 & 1.571 & 1.170 & 1.619 & 1.211 & 0.729 & 1.5 \\
\hline
\end{tabular}

Table 10. Aggregated pairwise comparison matrix of 3 decision makers for the sub-criteria.

\begin{tabular}{|c|c|c|c|c|}
\hline & SC11 & SC12 & SC13 & SC14 \\
\hline SC11 & 1.5 & 1.036 & 1.683 & 1.709 \\
\hline $\mathrm{SC} 12$ & 1.964 & 1.5 & 2.147 & 2.173 \\
\hline $\mathrm{SC} 13$ & 1.317 & 0.853 & 1.5 & 1.526 \\
\hline $\mathrm{SC} 14$ & 1.291 & 0.827 & 1.474 & 1.5 \\
\hline
\end{tabular}


The normalized fuzzy preference relation matrices for main and sub-criteria are calculated by using the CFPR method (Table 11, 12).

Table 11. Normalized fuzzy preference relation matrix for the main criteria.

\begin{tabular}{|l|c|c|c|c|c|c|c|}
\hline & MC1 & MC2 & MC3 & MC4 & MC5 & MC6 & MC7 \\
\hline MC1 & 0.130 & 0.130 & 0.127 & 0.131 & 0.127 & 0.119 & 0.130 \\
\hline MC2 & 0.122 & 0.123 & 0.117 & 0.123 & 0.118 & 0.104 & 0.122 \\
\hline MC3 & 0.156 & 0.156 & 0.159 & 0.155 & 0.159 & 0.167 & 0.156 \\
\hline MC4 & 0.117 & 0.119 & 0.112 & 0.119 & 0.113 & 0.096 & 0.118 \\
\hline MC5 & 0.153 & 0.152 & 0.155 & 0.152 & 0.155 & 0.161 & 0.153 \\
\hline MC6 & 0.194 & 0.192 & 0.206 & 0.190 & 0.204 & 0.237 & 0.194 \\
\hline MC7 & 0.128 & 0.129 & 0.124 & 0.129 & 0.125 & 0.115 & 0.128 \\
\hline
\end{tabular}

Table 12. Normalized fuzzy preference relation matrix for the sub-criteria.

\begin{tabular}{|l|l|l|l|l|}
\hline & SC11 & SC12 & SC13 & SC14 \\
\hline SC11 & 0.247 & 0.246 & 0.247 & 0.247 \\
\hline SC12 & 0.323 & 0.356 & 0.316 & 0.315 \\
\hline SC13 & 0.217 & 0.202 & 0.220 & 0.221 \\
\hline SC14 & 0.213 & 0.196 & 0.217 & 0.217 \\
\hline
\end{tabular}

Finally, the importance weight of the main criteria and sub-criteria determined by three decisionmakers using CFPR can be seen from Table 13 and Table 14, respectively.

Table 13. Importance weight of the main criteria.

\begin{tabular}{|l|c|}
\hline & Importance Weight \\
\hline MC1 & 0.127 \\
\hline MC2 & 0.118 \\
\hline MC3 & 0.158 \\
\hline MC4 & 0.113 \\
\hline MC5 & 0.154 \\
\hline MC6 & 0.203 \\
\hline MC7 & 0.125 \\
\hline
\end{tabular}

Table 14. Importance weight of the sub-criteria.

\begin{tabular}{|l|c|}
\hline & Importance Weight \\
\hline $\mathrm{SC} 11$ & 0.247 \\
\hline $\mathrm{SC} 12$ & 0.327 \\
\hline $\mathrm{SC} 13$ & 0.215 \\
\hline $\mathrm{SC} 14$ & 0.211 \\
\hline
\end{tabular}

The importance weight and the ranking for each set of sub-criteria are shown in Table 15.

Table 15. Importance weight of the criteria calculated

\begin{tabular}{|c|c|c|c|c|c|c|c|}
\hline $\begin{array}{c}\text { Main } \\
\text { Criter } \\
\text { ia }\end{array}$ & $\begin{array}{c}\text { Weig } \\
\text { ht }\end{array}$ & $\begin{array}{c}\text { Ran } \\
\text { king } \\
\text { of } \\
\text { MC }\end{array}$ & $\begin{array}{c}\text { Subcri } \\
\text { teria }\end{array}$ & $\begin{array}{c}\text { Local } \\
\text { Weight }\end{array}$ & $\begin{array}{c}\text { Ranki } \\
\text { ng } \\
\text { of SC }\end{array}$ & $\begin{array}{c}\text { Global } \\
\text { Weigh } \\
\text { t }\end{array}$ & $\begin{array}{l}\text { Ran } \\
\text { king }\end{array}$ \\
\hline \multirow{4}{*}{$\mathrm{MC} 1$} & \multirow{4}{*}{0.127} & \multirow{4}{*}{4} & SC11 & 0.247 & 11 & 0.031 & 17 \\
\hline & & & $\mathrm{SC} 12$ & 0.327 & 5 & 0.042 & 8 \\
\hline & & & $\mathrm{SC} 13$ & 0.215 & 14 & 0.027 & 20 \\
\hline & & & SC14 & 0.211 & 15 & 0.027 & 21 \\
\hline \multirow{3}{*}{$\mathrm{MC} 2$} & \multirow{3}{*}{0.118} & \multirow{3}{*}{6} & $\mathrm{SC} 21$ & 0.308 & 6 & 0.036 & 12 \\
\hline & & & $\mathrm{SC} 22$ & 0.252 & 10 & 0.030 & 19 \\
\hline & & & $\mathrm{SC} 23$ & 0.440 & 1 & 0.052 & 2 \\
\hline \multirow{4}{*}{ MC3 } & \multirow{4}{*}{0.158} & \multirow{4}{*}{2} & SC31 & 0.299 & 7 & 0.047 & 4 \\
\hline & & & SC32 & 0.299 & 7 & 0.047 & 4 \\
\hline & & & SC33 & 0.199 & 19 & 0.031 & 16 \\
\hline & & & SC34 & 0.204 & 18 & 0.032 & 15 \\
\hline \multirow{8}{*}{ MC4 } & \multirow{8}{*}{0.113} & \multirow{8}{*}{7} & SC41 & 0.093 & 29 & 0.011 & 29 \\
\hline & & & SC42 & 0.125 & 26 & 0.014 & 26 \\
\hline & & & SC43 & 0.150 & 22 & 0.017 & 22 \\
\hline & & & SC44 & 0.129 & 25 & 0.015 & 25 \\
\hline & & & SC45 & 0.150 & 22 & 0.017 & 22 \\
\hline & & & SC46 & 0.146 & 23 & 0.017 & 23 \\
\hline & & & SC47 & 0.107 & 27 & 0.012 & 27 \\
\hline & & & SC48 & 0.099 & 28 & 0.011 & 28 \\
\hline \multirow{3}{*}{ MC5 } & \multirow{3}{*}{0.154} & \multirow{3}{*}{3} & SC51 & 0.270 & 9 & 0.042 & 9 \\
\hline & & & SC52 & 0.402 & 2 & 0.062 & 1 \\
\hline & & & SC53 & 0.329 & 4 & 0.051 & 3 \\
\hline \multirow{5}{*}{ MC6 } & \multirow{5}{*}{0.203} & \multirow{5}{*}{1} & SC61 & 0.205 & 17 & 0.042 & 10 \\
\hline & & & SC62 & 0.209 & 16 & 0.042 & 7 \\
\hline & & & SC63 & 0.170 & 21 & 0.034 & 14 \\
\hline & & & SC64 & 0.220 & 13 & 0.044 & 5 \\
\hline & & & SC65 & 0.197 & 20 & 0.040 & 11 \\
\hline \multirow{4}{*}{ MC7 } & \multirow{4}{*}{0.125} & \multirow{4}{*}{5} & SC71 & 0.240 & 12 & 0.030 & 18 \\
\hline & & & SC72 & 0.344 & 3 & 0.043 & 6 \\
\hline & & & SC73 & 0.130 & 24 & 0.016 & 24 \\
\hline & & & SC74 & 0.286 & 8 & 0.036 & 13 \\
\hline
\end{tabular}

According to Table 15, it can be said that the most important main criteria for an inclusive campus environment are Greenness (MC6) > Connectivity $(\mathrm{MC} 3)>$ Living campus $($ MC5) and the most important subcriteria are Making Programs to Encourage Interdisciplinary Cooperation (SC23)> Expanding and Diversifying Housing Options on 
Campus (SC52) > Constructing Conference Centers, Student Cafeterias, Student Clubs, Theaters and Alumni Centers (SC72). Overall ranking according to the global weight calculated using CFPR are Expanding and Diversifying Housing Options on Campus (SC52) $>$ Making Programs to Encourage Interdisciplinary Cooperation (SC23)> Establishing Multidisciplinary Academic Facilities and Position them in the Core Campus (SC53).

\subsection{Computational Results of the CFPR methodology}

To weight the criteria using FANP methodology, the comparisons are made with experts using fuzzy scales, as shown in Table 2. Evaluations of the criteria by 3 experts were the same as the values of the CFPR methodology. The geometric mean of the decision-makers' evaluations is taken and the fuzzy comparison matrix of the main criteria and the fuzzy comparison matrix of the subcriteria SC11 can be seen in Table 16 and Table 17, respectively.

Table 16. The fuzzy comparison matrix of the main

\begin{tabular}{|c|c|c|c|c|c|c|c|c|c|c|c|c|c|c|c|c|c|c|c|c|c|}
\hline & \multicolumn{3}{|c|}{$\mathrm{MCl}$} & \multicolumn{3}{|c|}{ MC2 } & \multicolumn{3}{|c|}{ MC3 } & \multicolumn{2}{|c|}{ MC4 } & \multicolumn{3}{|c|}{ MC5 } & \multicolumn{4}{|c|}{ MC6 } & \multicolumn{3}{|c|}{\begin{tabular}{|l|l} 
MC7 \\
\end{tabular}} \\
\hline $\mathrm{M}$ & 1 & 1 & 1 & 1 & 1 & & 0. & & & | & & 30 & 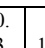 & & & $\begin{array}{l}0 . \\
1\end{array}$ & 0. & 0. & 1 & & 13 \\
\hline M & & & & & & & 0. & & & & & 10 & & & & 0. & 0. & 0 . & & & \\
\hline $\mathrm{C} 2$ & 1 & 1 & 1 & 1 & 1 & & 1 & & 3 & 1 & & \begin{tabular}{ll|}
3 & 3
\end{tabular} & 1 & & & 1 & 1 & 2 & 1 & & 3 \\
\hline $\begin{array}{l}\mathrm{M} \\
\mathrm{C} 3\end{array}$ & 3 & 5 & 7 & 3 & 5 & 7 & 1 & & 1 & 5 & & $\begin{array}{lll}9 & 1\end{array}$ & 3 & & & $\begin{array}{l}0 . \\
3\end{array}$ & 1 & 1 & ( & & 9 \\
\hline $\bar{M}$ & 0. & & & 0. & & & 0. & & & & & 0 & . & & & 0. & 0. & 0. & & & \\
\hline C4 & 3 & 1 & 1 & 3 & 1 & & 1 & & 2 & 1 & & 12 & 2 & & & 1 & 1 & 1 & 1 & 1 & 1 \\
\hline M & & & & & & & 0. & & & & & & & & & 0. & 0. & 0. & & & \\
\hline C5 & 1 & 1 & 3 & 1 & 1 & & 2 & & 1 & 1 & & \begin{tabular}{l|l}
5 & 1
\end{tabular} & 1 & & & 1 & 2 & 3 & 1 & 3 & 5 \\
\hline $\begin{array}{l}\mathrm{M} \\
\mathrm{C}\end{array}$ & 5 & 7 & 9 & 5 & 7 & 9 & 1 & & 3 & 7 . & & $\begin{array}{ll}9 & 3\end{array}$ & 3 & & & 1 & 1 & 1 & 7 & 9 & 9 \\
\hline $\bar{M}$ & & & & 0. & & & & & & & & & & & & & 0 & & & & \\
\hline C7 & 3 & 1 & 1 & 3 & 1 & 1 & 1 & & 2 & 1 & & 2 & 2 & & & 1 & 1 & 1 & 1 & 1 & 1 \\
\hline
\end{tabular}

Table 17. The fuzzy comparison matrix of the subcriteria SC1.

\begin{tabular}{|c|c|c|c|c|c|c|c|c|c|c|c|c|}
\hline & \multicolumn{3}{|c|}{ SC11 } & \multicolumn{3}{c|}{ SC12 } & \multicolumn{3}{c|}{ SC13 } & \multicolumn{3}{c|}{ SC14 } \\
\hline SC11 & 1 & 1 & 1 & 0.11 & 0.14 & 0.20 & 1 & 1 & 3 & 1 & 3 & 5 \\
\hline SC12 & 5 & 7 & 9 & 1.00 & 1 & 1 & 7 & 9 & 9 & 9 & 9 & 9 \\
\hline SC13 & 0.33 & 1 & 1 & 0.11 & 0.11 & 0.14 & 1 & 1 & 1 & 1 & 1 & 3 \\
\hline SC14 & 0.2 & 0.33 & 1 & 0.11 & 0.11 & 0.11 & 0.33 & 1 & 1 & 1 & 1 & 1 \\
\hline
\end{tabular}

The fuzzy weight matrix of the criteria according to the goal and the fuzzy weight matrix of the subcriteria are given in Tables 18, and 19, respectively. The evaluation and the methodology described above produced the results shown in Table 20.
Table 18. Fuzzy weight matrix of the criteria according to the goal.

\begin{tabular}{|c|c|c|c|}
\hline & $\mathrm{L}$ & $\mathrm{M}$ & $\mathrm{U}$ \\
\hline $\mathrm{MC} 1$ & 0.033 & 0.058 & 0.128 \\
\hline $\mathrm{MC} 2$ & 0.033 & 0.058 & 0.128 \\
\hline MC3 & 0.128 & 0.310 & 0.567 \\
\hline MC4 & 0.021 & 0.045 & 0.083 \\
\hline MC5 & 0.042 & 0.089 & 0.256 \\
\hline MC6 & 0.224 & 0.394 & 0.748 \\
\hline MC7 & 0.021 & 0.045 & 0.083 \\
\hline
\end{tabular}

Table 19. Fuzzy weight matrix of the subcriteria.

\begin{tabular}{|l|c|c|c|}
\hline & $\mathrm{L}$ & $\mathrm{M}$ & $\mathrm{U}$ \\
\hline $\mathrm{SC} 11$ & 0.005 & 0.010 & 0.022 \\
\hline SC12 & 0.0302 & 0.057 & 0.114 \\
\hline SC13 & 0.004 & 0.007 & 0.014 \\
\hline SC14 & 0.003 & 0.005 & 0.011 \\
\hline SC21 & 0.004 & 0.008 & 0.0160 \\
\hline SC22 & 0.002 & 0.004 & 0.007 \\
\hline SC23 & 0.0178 & 0.037 & 0.072 \\
\hline SC31 & 0.0302 & 0.057 & 0.110 \\
\hline SC32 & 0.0302 & 0.057 & 0.114 \\
\hline SC33 & 0.005 & 0.010 & 0.022 \\
\hline SC34 & 0.005 & 0.010 & 0.022 \\
\hline SC41 & 0.004 & 0.007 & 0.014 \\
\hline SC42 & 0.007 & 0.015 & 0.039 \\
\hline SC43 & 0.020 & 0.042 & 0.081 \\
\hline SC44 & 0.011 & 0.028 & 0.059 \\
\hline SC45 & 0.0201 & 0.041 & 0.081 \\
\hline SC46 & 0.0201 & 0.041 & 0.081 \\
\hline SC47 & 0.005 & 0.010 & 0.022 \\
\hline SC48 & 0.005 & 0.010 & 0.022 \\
\hline SC51 & 0.002 & 0.004 & 0.007 \\
\hline SC52 & 0.007 & 0.015 & 0.0393 \\
\hline SC53 & 0.004 & 0.007 & 0.014 \\
\hline SC61 & 0.041 & 0.080 & 0.151 \\
\hline SC62 & 0.041 & 0.080 & 0.151 \\
\hline SC63 & 0.021 & 0.042 & 0.078 \\
\hline SC64 & 0.041 & 0.080 & 0.140 \\
\hline SC65 & 0.0302 & 0.057 & 0.114 \\
\hline SC71 & 0.020 & 0.042 & 0.081 \\
\hline SC72 & 0.058 & 0.106 & 0.194 \\
\hline SC73 & 0.002 & 0.004 & 0.007 \\
\hline SC74 & 0.011 & 0.027 & 0.059 \\
\hline & & & \\
\hline
\end{tabular}


Table 20. Importance weight of the criteria calculated using FANP.

\begin{tabular}{|c|c|c|c|c|c|c|c|}
\hline $\begin{array}{l}\text { Main } \\
\text { Criteria }\end{array}$ & Weight & $\begin{array}{l}\text { Ra } \\
\text { nk } \\
\text { ing } \\
\text { of } \\
\text { M } \\
\text { C }\end{array}$ & $\begin{array}{l}\text { Subc } \\
\text { riteri } \\
\text { a }\end{array}$ & $\begin{array}{l}\text { Local } \\
\text { Weight }\end{array}$ & $\begin{array}{l}\text { Ran } \\
\text { king }\end{array}$ & $\begin{array}{l}\text { Global } \\
\text { Weight }\end{array}$ & $\begin{array}{l}\text { Ran } \\
\text { king }\end{array}$ \\
\hline \multirow{4}{*}{ MC1 } & \multirow{4}{*}{0.073} & \multirow{4}{*}{4} & SC11 & 0.012 & 12 & 0.001 & 17 \\
\hline & & & $\mathrm{SC} 12$ & 0.067 & 4 & 0.005 & 8 \\
\hline & & & $\mathrm{SC} 13$ & 0.008 & 14 & 0.001 & 20 \\
\hline & & & SC14 & 0.006 & 15 & \begin{tabular}{|l|l}
0.0004 \\
\end{tabular} & 22 \\
\hline \multirow{3}{*}{$\mathrm{MC} 2$} & \multirow{3}{*}{0.073} & \multirow{3}{*}{4} & $\mathrm{SC} 21$ & 0.010 & 13 & 0.001 & 18 \\
\hline & & & $\mathrm{SC} 22$ & 0.004 & 17 & 0.0003 & 24 \\
\hline & & & SC23 & 0.042 & 8 & 0.003 & 10 \\
\hline \multirow{4}{*}{ MC3 } & \multirow{4}{*}{0.335} & \multirow{4}{*}{2} & SC31 & 0.066 & 5 & 0.022 & 5 \\
\hline & & & SC32 & 0.067 & 4 & 0.022 & 4 \\
\hline & & & SC33 & 0.012 & 12 & \begin{tabular}{|l|}
0.004 \\
\end{tabular} & 9 \\
\hline & & & SC34 & 0.012 & 12 & 0.004 & 9 \\
\hline \multirow{8}{*}{ MC4 } & \multirow{8}{*}{0.0499} & \multirow{8}{*}{5} & SC41 & 0.008 & 14 & 0.0004 & 23 \\
\hline & & & SC42 & 0.021 & 11 & 0.001 & 16 \\
\hline & & & SC43 & 0.048 & 6 & 0.002 & 12 \\
\hline & & & SC44 & 0.033 & 9 & 0.002 & 13 \\
\hline & & & SC45 & 0.048 & 6 & 0.002 & 12 \\
\hline & & & SC46 & 0.048 & 6 & 0.002 & 12 \\
\hline & & & SC47 & 0.012 & 12 & 0.0006 & 19 \\
\hline & & & SC48 & 0.0123 & 12 & 0.0006 & 19 \\
\hline \multirow{3}{*}{ MC5 } & \multirow{3}{*}{0.129} & \multirow{3}{*}{3} & SC51 & 0.004 & 17 & 0.0006 & 21 \\
\hline & & & SC52 & 0.021 & 11 & 0.003 & 11 \\
\hline & & & SC53 & 0.008 & 14 & 0.001 & 15 \\
\hline \multirow{5}{*}{ MC6 } & \multirow{5}{*}{0.455} & \multirow{5}{*}{1} & SC61 & 0.091 & 2 & 0.041 & 1 \\
\hline & & & SC62 & 0.091 & 2 & 0.041 & 1 \\
\hline & & & SC63 & 0.047 & 7 & 0.021 & 6 \\
\hline & & & SC64 & 0.087 & 3 & 0.040 & 2 \\
\hline & & & SC65 & 0.067 & 4 & 0.031 & 3 \\
\hline \multirow{4}{*}{ MC7 } & \multirow{4}{*}{0.050} & \multirow{4}{*}{5} & SC71 & 0.048 & 6 & 0.002 & 12 \\
\hline & & & SC72 & 0.119 & 1 & 0.006 & 7 \\
\hline & & & SC73 & 0.005 & 16 & 0.0002 & 25 \\
\hline & & & SC74 & 0.033 & 10 & 0.002 & 14 \\
\hline
\end{tabular}

According to Table 19, it can be said that the most important main criteria for inclusive campus environment are Greenness (MC6) > Connectivity (MC3) > Living campus (MC5) and the most important subcriteria are Constructing Conference Centers, Student Cafeterias, Student Clubs, Theaters and Alumni Centers (SC72) > Designing Landscapes to Create Vivid Open Spaces (SC61) =
Protect Park-Like Campuses (SC62) > Fulfilling Ecological Functions to Create a more Manageable Parking Space (SC64). Overall ranking according to the global weight calculated using FANP are Designing Landscapes to Create Vivid Open Spaces $($ SC61 $)=$ Protect Park-Like Campuses (SC62) $>$ Fulfilling Ecological Functions to Create a more Manageable Parking Space (SC64) > Developing Local Vegetation by Integrating it into the Campus Landscape (SC65).

\section{Conclusion}

The concept of Inclusive Design has emerged to ensure that individuals can benefit from all opportunities equally. The inclusive environment ensures equal opportunities and participation of all. Inclusive design is not only an architectural problem but also a political, economic, social, and technological issue. Since university campuses are evaluated in the context of small cities or public spaces, they should be equally accessible to everyone. In order to give equal rights in campus design, the inclusive campus design criteria must be met.

Although the physical environment is the source of some opportunities, the physical environment of the campus has a great psychological impact. Having socialization areas on campus directs individuals to spend more time on campus. Social opportunities offered by the campus; Structures such as show areas and sports halls turn the campus into a living space and have positive psychological effects. All these facilities can be used by everyone and designed with the principles of inclusiveness creates a positive effect [3].

In this paper, CFPR and FANP methodologies are used to evaluate of inclusive campus environment design criteria. As a result of the evaluation process, both of these two MCDM methods, CFPR and FANP, have determined the most important main criteria for an inclusive campus environment as Greenness (MC6), Connectivity (MC3), and Living campus (MC5).

The most important subcriteria determined using CFPR are Making Programs to Encourage Interdisciplinary Cooperation (SC23), Expanding and Diversifying Housing Options on Campus (SC52), and Constructing Conference Centers, Student Cafeterias, Student Clubs, Theaters and Alumni Centers (SC72). On the other hand, the most important subcriteria determined using FANP are Constructing Conference Centers, Student Cafeterias, Student Clubs, Theaters and Alumni Centers (SC72), Designing Landscapes to Create 
Vivid Open Spaces (SC61), Protect Park-Like Campuses (SC62), and Fulfilling Ecological Functions to Create a more Manageable Parking Space (SC64). Also, this causes variation in the overall ranking.

The reason for this difference can be thought of as, at the FANP calculation step, all of the pairwise comparisons are taken into account. FANP methodology considers interactivity among all subcriteria. The main contribution of this paper is to prioritize the inclusive campus environment criteria using numerical methods with experts' views.

For future research, this problem can be studied with the help of other MCDM methods. In addition, trapezoidal fuzzy sets could be used instead of triangular fuzzy sets for the decision-making phase and intelligent software can be developed to automatically obtain solutions.

\section{References:}

[1] Mace, R. (1985). Universal Design, Barrier free environments for everyone. Designers West, Los Angeles.

[2] Prellwitz, M. (2007). Playgrounds Accessibility and Usability for Children with Disabilities. Luleå University of Technology Department of Human Work Sciences, PhD Thesis, Sweden.

[3] Ozdemir, S. (2019). An Assessment Tool Proposal for Making University Campuses Suitable for the Inclusive Design Concept. Yildiz Technical University, Institute of Science, $\mathrm{PhD}$ Thesis, Istanbul.

[4] Direk, S.Y., Erdogan, F. (2016). Disabled Children in Cities and Traditional Play Culture. Design for All and Accessible Cities 2nd National Symposium on the Disabled, 7-8-9 April, Konya.

[5] Kenney, D.R., Dumont, R., Kenney, G.S. (2005). Mission and place: Strengthening learning and community through campus design. CT: Praeger Publishers, Westport.

[6] Pohekar, S. D., \& Ramachandran, M. (2004). Application of multi-criteria decision making to sustainable energy planning-A review. Renewable and sustainable energy reviews, 8(4), 365-381.

[7] Kahraman, C. (Ed.). (2008). Fuzzy multi-criteria decision making: theory and applications with recent developments (Vol. 16). Springer Science \& Business Media.

[8] Opricovic, S., \& Tzeng, G. H. (2004). Compromise solution by MCDM methods: A comparative analysis of VIKOR and TOPSIS. European journal of operational research, 156(2), 445-455.

[9] Patel, D. A., Kikani, K. D., \& Jha, K. N. (2016). Hazard assessment using consistent fuzzy preference relations approach. Journal of Construction Engineering and Management, 142(12), 04016067.
[10] Alias, F. M. A., \& Abdullah, L. (2017). Consistent Fuzzy Preference Relation Method and Its Application to Criteria Assessment of Quality of Life Among Population of Setiu Wetlands. Discovering Mathematics (Menemui Matematik), 39(2), 52-60.

[11] Chao, R. J. (2017). Using Consistent Fuzzy Preference Relations for the Selection of A Smartphone-A Case Study of Students of a University in Southern Taiwan. Journal of Kao Yuan University Vol, 22, 126-132.

[12] Cheng, C. H., Liou, J. J., \& Chiu, C. Y. (2017). A consistent fuzzy preference relations based ANP model for R\&D project selection. Sustainability, 9(8), 1352

[13] Ozdemir, Y., Nalbant, K. G., \& Basligil, H. (2017). Evaluation of personnel selection criteria using Consistent Fuzzy Preference Relations. International Journal of Management Science, 4(6), 76-81.

[14] Alias, F. M. A., Abdullah, L., Gou, X., Liao, H., \& Herrera-Viedma, E. (2019). Consistent fuzzy preference relation with geometric Bonferroni mean: a fused preference method for assessing the quality of life. Applied Intelligence, 49(7), 26722683.

[15] Park, Y. I., Lu, W., Nam, T. H., \& Yeo, G. T. (2019). Terminal vitalization strategy through optimal route selection adopting CFPR methodology. The Asian Journal of Shipping and Logistics, 35(1), 41-48.

[16] Huynh, N. X., \& Phi, H. D. (2020). Applying Consistency Fuzzy Preference Relations to Select a Strategy that Attracts Foreign Direct Investment (FDI) in Developing Supporting Industries for Vietnam. In Foreign Direct Investment Perspective Through Foreign Direct Divestment. IntechOpen.

[17] Hemmati, N., Rahiminezhad Galankashi, M., Imani, D.M., Farughi, H. (2018) Maintenance policy selection: a fuzzy-ANP approach. Journal of Manufacturing Technology Management 29(7):1253-1268.

[18] Danai, H., Hashemnia, S., Ahmadi, R., Bazazzadeh, S.H. (2019). Application of fuzzy ANP method to select the best supplier in the supply chain. International Journal of Operational Research 35(1):1-19.

[19] Alilou, H., Rahmati, O., Singh, V.P., Choubin, B., Pradhan, B., Keesstra, S., Sadeghi, S.H. (2019). Evaluation of watershed health using Fuzzy-ANP approach considering geo-environmental and topohydrological criteria. Journal of Environmental Management 232:22-36.

[20] Galankashi, M.R., Rafiei, F.M., Ghezelbash, M. (2020). Portfolio selection: a fuzzy-ANP approach. Financial Innovation 6(1):1-34.

[21] Ozdemir, Y., Nalbant, K.G., Basligil, H., "Personnel Selection for Promotion Using an Integrated Fuzzy Analytic Hierarchy Process-Grey Relational Analysis Methodology: A Real Case Study", Anadolu University Journal of Science and 
Technology A - Applied Sciences and Engineering (AUJST-A), doi:10.18038/aubtda.326726, 19(2): 278-292, (2018).

[22] Ozdemir, Y., Nalbant, K.G., "A Real Personnel Selection Problem using the Generalized Choquet Integral Methodology", Business \& Management Studies: An International Journal, 6(2): 694-716, (2018).

[23] Nalbant, K.G., Ozdemir, Y., "Personnel Selection Using Fuzzy VIKOR Methodology", International Journal of Management Science, 5(2), 10-17, (2018).

[24] Petrović, G., Mihajlović, J., Ćojbašić, Ž., Madić, M., \& Marinković, D. (2019). Comparison of three fuzzy MCDM methods for solving the supplier selection problem. Facta Universitatis, Series: Mechanical Engineering, 17(3), 455-469.

[25] Ozdemir, S., Ozdemir, Y., Nalbant, K.G., "Evaluating Campus Components According to the Inclusive Design Principles Using CFPR and FANP Methodologies", in: Academic Researches in Architecture, Planning and Design Sciences, ed. Prof. Latif Gurkan Kaya, Ph.D.,Platanus Publishing, ISBN: 978-625-7767-71-2, (October 2020).

[26] Chowdhury, P., \& Paul, S. K. (2020). Applications of MCDM methods in research on corporate sustainability: a systematic literature review. Management of Environmental Quality: An International Journal.

[27] Ozdemir, Y., Ozdemir, S., Nalbant, K.G. "A Hybrid Methodology for Prioritizing of Store Plan Alternatives Produced with Ruled Based Design", International Journal of Information Technology \& Decision Making, 20, (2021).

[28] Paul, A., Shukla, N., Paul, S. K., \& Trianni, A. (2021). Sustainable Supply Chain Management and Multi-Criteria Decision-Making Methods: A Systematic Review. Sustainability, 13(13), 7104.

[29] Hajrasouliha, A.H. (2015). The morphology of the "well-designed campus": Campus design for a sustainable and livable learning environment. The University of Utah, PhD Thesis, Utah.

[30] Coulson, J., Roberts, P., Taylor, I. (2010). University planning and architecture: The search for perfection. Routledge, Abington.

[31] Haar, S. (2011). The city as campus: Urbanism and higher education in Chicago. University of Minnesota Press, Minneapolis.

[32] Herrera-Viedma, E., Herrera, F., Chiclana, F., \& Luque, M. (2004). Some issues on consistency of fuzzy preference relations. European journal of operational research, 154(1), 98-109.

[33] Chang, T. H., Hsu, S. C., \& Wang, T. C. (2013). A proposed model for measuring the aggregative risk degree of implementing an RFID digital campus system with the consistent fuzzy preference relations. Applied Mathematical Modelling, 37(5), 2605-2622.

[34] Wang, T. C., \& Lin, Y. L. (2009). Applying the consistent fuzzy preference relations to select merger strategy for commercial banks in new financial environments. Expert Systems with Applications, 36(3), 7019-7026.

[35] Jafarnejad, A., Ebrahimi, M., Abbaszadeh, M. A., \& Abtahi, S. M. (2014). Risk management in supply chain using consistent fuzzy preference relations. International Journal of Academic Research in Business and Social Sciences, 4(1), 77.

[36] Ozdemir, Y., \& Nalbant, K. G. (2020). Personnel Selection for Promotion using an Integrated Consistent Fuzzy Preference Relations-Fuzzy Analytic Hierarchy Process Methodology: A Real Case Study. Asian Journal of Interdisciplinary Research, 3(1), 219-236.

[37] Saaty, T. L. (1996). Decision making with dependence and feedback the analytic network process (RWS Publications, Pittsburgh).

[38] Rezaeiniya, N., Ghadikolaei, A. S., Mehri-Tekmeh, J., \& Rezaeiniya, H. (2014). Fuzzy ANP approach for new application: Greenhouse Location selection; a case in Iran. Journal of mathematics and computer Science, 8(1), 1-20.

[39] Hsieh, T. Y., Lu, S. T., Tzeng, G. H. (2004). Fuzzy MCDM approach for planning and design tenders selection in public office buildings. International Journal of Project Management 22, 573-584.

[40] Haghighi, M., Divandari, A., Keimasi, M. (2010). The impact of 3D e-readiness on e-banking development in Iran: A fuzzy AHP analysis. Expert Systems with Applications 37, 4084-4093.

[41] Kaya, T., Kahraman, C. (2011). An integrated fuzzy AHP-ELECTRE methodology for environmental impact assessment. Expert System with Application 38, 8553-8562.

[42] Yasmin, F., Kumar, A., Kumar, A. (2013). Fuzzy Theory Concept Applied in Analytic Network Process. International Journal of Advanced Research in Computer Science and Software Engineering 3, 832-837.

[43] Ozdemir, Y., \& Ozdemir, S. (2020). Weighting The Universal Design Principles Using Multi-Criteria Decision Making Techniques. Journal of Engineering Sciences and Design, 8(1), 105-118.

\section{Contribution of individual authors to the creation of a scientific article (ghostwriting policy)}

All authors conceived of the presented idea. Sahika Ozdemir developed the theory. Kemal Gokhan Nalbant designed the model and the computational framework. Kemal Gokhan Nalbant and Yavuz Ozdemir performed the computations. Sahika Ozdemir supervised the findings of this work. Kemal Gokhan Nalbant wrote the manuscript with support from Sahika Ozdemir and Yavuz Ozdemir. 
All authors discussed the results and contributed to the final manuscript.

Sources of funding for research presented in a scientific article or scientific article itself

The authors received no financial support for the research, authorship, and/or publication of this article.

\section{Creative Commons Attribution License 4.0} (Attribution 4.0 International, CC BY 4.0)

This article is published under the terms of the Creative Commons Attribution License 4.0

https://creativecommons.org/licenses/by/4.0/deed.en US 